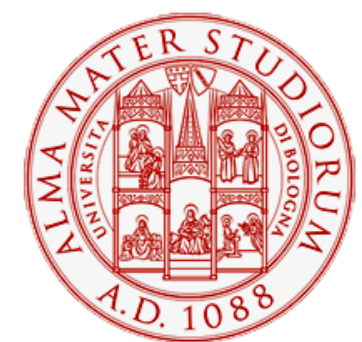

Alma Mater Studiorum - Università di Bologna DEPARTMENT OF ECONOMICS

Persistence of high income inequality and banking crises: 1980-2010

Giorgio Bellettini

Flavio Delbono

Quaderni - Working Paper DSE N885

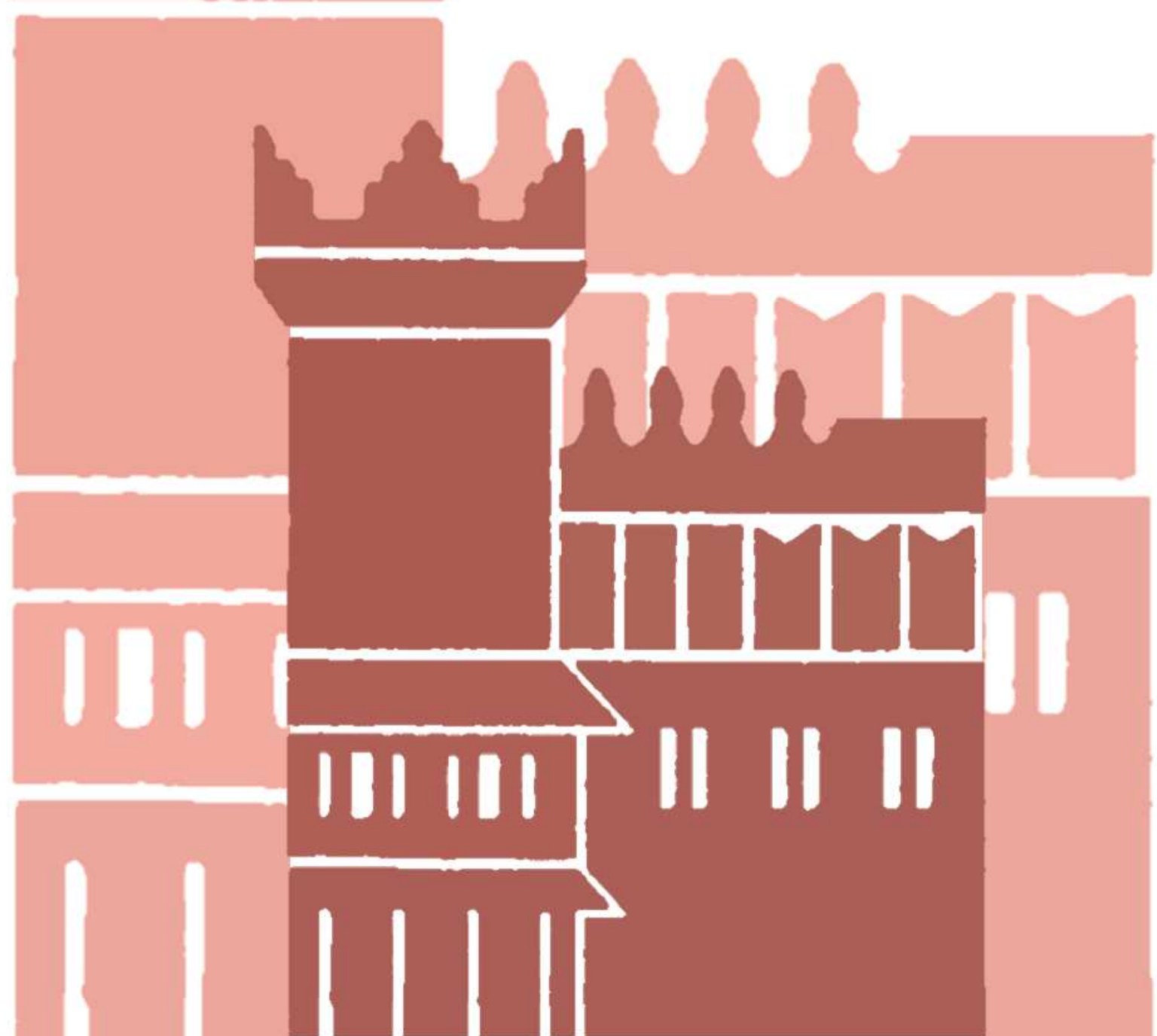




\title{
Persistence of high income inequality and banking crises: 1980-2010
}

\author{
Giorgio Bellettini` and Flavio Delbono`
}

May 2013

(Preliminary draft, not to be quoted without permission)

Abstract. Differently from Atkinson and Morelli (2011) who detect no clear link between increases in income inequality and systemic banking crises, we show that a large majority of crises occurred between 1982 and 2008 have been preceded by persistently high levels of income inequality. Such association is robust when considering Gini values for incomes after-tax as well as before-tax and transfers. Moreover, we investigate the pattern of income inequality levels before and after a group of banking crises and the relative levels of income inequality in a large sample of OECD countries that did not experience banking crises between 1980 and 2010.

- Department of Economics, University of Bologna. We thank Flavia Moi for research assistance and Marco Mira d'Ercole (OECD) and Salvatore Morelli (Oxford University) for helpful suggestions about the dataset. giorgio.bellettini@unibo.it ; flavio.delbono@unibo.it . 


\section{Introduction}

In the last three decades - and especially in the '90s - many developed countries have experienced significant increases in income inequality. Between mid-1980s and the late 2000s the value of the Gini index (for disposable incomes) grew by almost $10 \%$ in OECD countries ${ }^{1}$ and similar trends are observable also elsewhere. Some emerging countries (like Brazil, India, Indonesia, South Africa) actually show inequality increases even higher than most OECD economies.

By looking at the evolution of the distribution of household income, some scholars ${ }^{2}$ have also detected that the increase in inequality was often driven by remarkable rising in top income shares (top 1\%, for instance). This phenomenon has been especially observed initially in English-speaking countries and later also in continental Europe and Japan. In this group of countries, after a significant reduction over time, top incomes shares started growing in the '70s and reached their peaks in the late 2000s.

The similar trends in income concentration that one may recognize in the US before the 1929 financial crisis and before the 2007 one have probably motivated some economists to look closer at the relationship between income inequality and banking (and economic) crises. Stiglitz (2012) argues forcefully that the increasingly uneven income distribution undermined US households consumption especially in the lower part of the distribution. Households reacted to stagnating incomes by expanding their borrowing to keep track with their expected living standard. Such credit boom in a poorly regulated and risk-loving financial system later proved unsustainable. The explosion of the housing bubble then fired the flammable banking sector. Fitoussi and Saraceno (2009), Milanovic (2009) and Stockhammer (2012) claim that the roots of the recent crisis have to be found in long-run structural changes in income distribution. ${ }^{3}$

Although evocative, the above arguments have not been submitted to empirical tests by their proponents and the belief that there may exist a link from inequality to crises needed to be challenged on statistical playgrounds. A first investigation has been performed in an important

\footnotetext{
${ }^{1}$ See OECD (2011).

${ }^{2}$ See Atkinson and Piketty (2011) for an excellent account of their own results and an updated survey of the relevant literature.

${ }^{3}$ See also the survey by van Treeck and Sturm (2012). Different views on the relationship between income inequality and financial crises have been debated also in the New York Times: see Story (2010).
} 
paper by Atkinson and Morelli (2011), AM11 henceforth. ${ }^{4}$ Postponing to section 2 the details of AM11, it is worth noting from now one of their main conclusions: there is no clear link between changes in income inequality and the occurrence of systemic banking crises.

Although the analysis and the results in AM11 are certainly very interesting, we think that one important element of the relationship between inequality and banking crises is missing in their investigation. Specifically, we believe that levels of income inequality are not less important than changes in trying to understand the association between income inequality and banking (and economic) crises. Hence, our paper aims at complementing AM11, by addressing their same basic question with reference to levels of income inequality for a subset of their sample of episodes of banking crises. We shall consider persistent (up to ten years long) high (above the timely OECD average) levels of overall income inequality (as measured by Gini coefficient) for systemic banking crises that occurred after 1945.

By performing a statistical analysis along the same lines of AM11, we checked how many countries, that experienced banking crises, fell above or below the relevant OECD average inequality level, used as a benchmark. Notwithstanding the severe limitations imposed by the availability of consistent data on Gini coefficients, our conclusions about the association between income inequality and banking crises are significantly different from AM11 ones.

Specifically, we find that: (1) using both after-tax and before-tax household incomes, a large majority of classifiable banking crises has been preceded by persistently high levels of Gini coefficients vis-à-vis the relevant OECD average; (2) the occurrence of banking crises does not seem to modify income inequality levels relative to timely OECD averages; (3) focusing on OECD countries that did not experience banking crises in the last thirty years, the number of highinequality countries is almost equal to the number of low-inequality ones, except for the 2000's when the latter slightly prevails on the former.

The rest of the paper is organized as follows. Section 2 reviews the contribution by Atkinson and Morelli (2011) and underlines the differences between their analysis and ours. Section 3 presents our results for the distribution of disposable income (i.e., after-tax and money transfers) and section 4 for income before-tax and transfers. Section 5 looks at the pattern of inequality before and after banking crises and investigates the levels of income inequality in countries that did not host banking crises. Section 6 concludes the paper.

\footnotetext{
${ }^{4}$ We focus on banking crises only, but AM11 also investigate the link between income inequality and economic (and consumption) crises.
} 


\section{The contribution of Atkinson and Morelli}

In AM11, Atkinson and Morelli investigate empirically the relationship between changes in income inequality and banking crises. They test both directions of the relationship: from income inequality to banking crises and vice-versa. Let us summarize their own approach and the conclusions.

First of all, they identify the systemic banking crises by using three different databases assembled by Bordo et al. (2001), Laeven and Valencia (2008) and (2010), Reinhart and Rogoff (2009) ${ }^{5}$. According to such criteria, they identify in the world 72 episodes in the period 1911-2010 (see their Table A.1). Hence, they focus on a subset of 37 banking crises occurred in years and countries where data on income distribution are available: "Information about an overall measure of inequality, typically the Gini coefficient, will be given priority with respect to any other measure of inequality in our database. In the absence of an overall measure, we will turn to top income shares and ultimately to the poverty index” (AM 11, p. 16).

Gini coefficients for equivalized household disposable incomes are their preferred figures; when these are not available, they use other statistics on household incomes (top 1\% income share and poverty index) and carefully motivate their choices. When using the Gini index as a measure of the distribution of income, if the crisis occurred at $\mathrm{T}$, they compare the average value of the Gini index for the years (T-6, T-5, T-4) with the value at (T-1). Then, they record a "change in income inequality” when the Gini index changes by about two thirds of a percentage point (say, from 0.30 to 0.3065$)$.

To be more precise, consider a banking crisis occurred in the $i$-th country at date $T$. Let us denote with $G_{i t}$ the value of Gini coefficient for country $i$ in year $t$ and with $G_{i}$ the average of Gini coefficients for country $i$ in the relevant period. The relevant period for AM11 is the time span [T-6, T-4]; hence, when using Gini coefficient, they compute $G_{i}$ as:

$$
G_{i}=\sum_{t=T-6}^{T-4} G_{i t} / 3
$$

and operate a partition as follows. Income inequality in the $i$-th country is considered to be:

increasing if $\left(G_{i}-G_{i, T-1}\right)>0.0065$;

decreasing if $\left(G_{i}-G_{i, T-1}\right)<-0.0065$;

\footnotetext{
${ }^{5}$ See AM11, Appendix, for the details of how they combine the criteria adopted in the three databases.
} 
stable if $\left(G_{i}-G_{i, T-1}\right) \in[-0.0065,+0.0065]$.

The quality of the dataset allow them to focus only 22 of the 37 banking crises initially considered. In 6 cases inequality increased before the crisis episodes; in 6 cases it declined; in 10 cases it varied by less than the critical threshold (see their Table 1). This evidence does not confirm the allegedly underlined link between trends in income distribution and systemic banking crises. Moreover, no clear pattern emerges in the trend of overall income inequality before and after the banking crises. In fact, as for the trend of income inequality after a banking crisis, they show that income inequality declined 8 times, was stable 8 times and increased 13 times. No clear pattern seems to emerge for overall income inequality as measured by the Gini coefficient, whereas changes in top shares seem to have some predictive power.

This is the summary of AM11 conclusions about the relationship between changes in income inequality and banking crises in 25 countries. As for the relevance of levels of income inequality, they plainly admit that "the level hypothesis cannot be ruled out at this stage” (AM11, p. 49). This is the starting point of our contribution.

Notice that AM11's conclusions have already affected the debate about the issue. For instance, Glaiser (2010) quote their paper to reject any correlation between income inequality and banking crises. Bordo and Meissner (2012) develop an empirical analysis to contrast the claim - put forward by Rajan (2010) and Kumhof and Ranciere (2010), for instance - that in the United States rising inequality led to a credit boom and eventually to a financial crisis both in the late ' 20 s and at the end of the last decade. Using top income shares for the measurement of inequality trends, Bordo and Meissner (2012) argue against the alleged inequality-credit-crisis nexus. ${ }^{6}$ Krugman (2012), without quoting AM11, looks quite skeptical about explanations of (banking and) economic crises based on the trend of increasing inequality observed especially in the USA. He does prefer to look for political arguments behind the deepest roots of the recent crisis.

\section{Inequality and banking crises: incomes after-tax and transfers}

In this section we investigate the relationship between persistently high levels of (disposable) income inequality and banking crises. More precisely, we proceed as follows:

(i) We adopt the same criteria as AM11 for the identification of systemic banking crises.

\footnotetext{
${ }^{6}$ A related paper by Bordo and Meissner (2011) will be commented in section 5 below. 
(ii) We use the value of Gini coefficient as a measure of overall inequality of household disposable incomes (see Appendix A.1).

(iii) For each banking crisis, we calculate the average value of the Gini coefficient between (T-10) and (T-1), where $\mathrm{T}$ is the start year of the banking crisis, supposed to last one year only. This means that, at most, we average 10 values, although in many cases we have to rely on less observations.

(iv) For each crisis, we compare the average value of Gini coefficients (for the country where the banking crisis took place) with the relevant value of the Gini average for OECD countries. When the relevant time interval includes two OECD averages (usually available every 5 years), we average them to obtain the threshold.

(v) By means of step (iv), we classify banking crises into two groups, depending on whether the Gini average value is above or below the threshold represented by the OECD average.

Our starting point is given by a subset of the 26 banking crises reported in AM11 (in their Table A.1) for the post-1945 period. In fact, step (iii) above and our requirements on the quality of the dataset (see Appendix A.1) allow us to collect the relevant information on income after-tax income inequality only for 14 episodes in 12 countries in the period 1984-2008, listed in Table 1.

\section{[Insert Table 1 here]}

Notice that 9 (out of 12) countries are OECD members and 11 (out of 14) banking crises occurred in OECD countries. This characteristic of our first sample makes the choice of the OECD average as benchmark a bit less discretionary. The group of 18 countries that have experienced banking crisis in the last thirty years include indeed many OECD members and, among them, the top-ranked economies in terms of aggregate GDP (excluding China).

Proceeding now as we explained through steps (ii)-(iv), we compute the relevant Gini indexes and the values of the OECD benchmarks. The relevant period, for us, goes back up to nine years with respect to the year before the start of the crisis. Hence,

$$
G_{i}=\sum_{t=T-10}^{T-1} G_{i t} / N_{i}
$$

where $N_{i}$ is the number of available observations for country $i$ in the relevant period. Let $G_{O T}$ be the average value of Gini coefficients for OECD countries available in the period between $t_{1}$ and $t_{2}$, 
where $\mathrm{t}_{1} \geq \mathrm{T}-10\left(\mathrm{t}_{2} \leq T-1\right)$ is the earliest (latest) year used to calculate $G_{i}$. We argue that, for a crisis occurred at time $T$ in country $i$, this country experienced persistently high income inequality before the banking crisis if $G_{i}>G_{O T}$, whereas it did not if $G_{i} \leq G_{O T}$.

Thus, while AM11 look at short-run changes in the levels of income inequality, we focus on longer-run levels of income inequality as compared to the relevant level of OECD average.

For each crisis we succeeded to classify, the third column of next table shows whether the average Gini index $G_{i}$ is above or below the average OECD Gini index $G_{O T}$. The Gini index $G_{i}$ was computed with an average number of 6.8 observations (years) per crisis (see Appendix A.1).

\section{[Insert Table 2 here]}

It turns out that 9 banking crises out of 14 have been preceded by persistently high levels of high (disposable) income inequality. Although the sample of banking crisis we succeed to classify is fairly small, the association does not look negligible at all. About two thirds of the banking episodes occurred in countries experiencing, before the crisis, levels of overall income inequality above the OECD average (see Figure 1).

\section{[Insert Figure 1 here]}

The average distance (across crises for countries above the OECD average) from the OECD average (source OECD) is 0,028 percentage Gini points, with a minimum difference of 0,0052 for Spain and a maximum difference of 0,054 for US in 2007. Eliminating these two outliers, the average distance becomes 0,027 . Thus, in general, our conclusions seem fairly robust to measurement errors and the potential bias induced by outliers.

In the data challenge, one concern is related to the choice of the benchmark. So far, we limited our attention to data on OECD countries provided by OECD itself. As a further control, we compute a different average of Gini coefficients in OECD countries using data from Luxembourg Income Studies (LIS). Such dataset provides our preferred income data on overall income inequality (that is, equivalized disposable household income) for several OECD countries in the last decades. ${ }^{7}$ The last column of Table 2 summarizes the outcome of this additional comparison between income

\footnotetext{
${ }^{7}$ The LIS dataset on incomes is precisely designed and built to ease cross-countries investigations.
} 
inequality indexes of our 12 countries and this newly computed benchmark (see Appendix A.2). The results of the third column are again confirmed. ${ }^{8}$

We are also aware that our income inequality data suffer from heterogeneity of sources, as we preferred to emphasize the length of countries' time series of Gini coefficient rather than the homogeneity of data sources across countries. To partly offset this limitation, we make a control using the LIS dataset. We select LIS available data on Gini coefficient in the decade before the banking crisis and we average them. Exactly as before, we then compare such averages with the relevant OECD averages (OECD source). Although the number of observations is smaller than in our previous sample ${ }^{9}$, our conclusions are confirmed for all 9 crises for which we have data. Unfortunately, we cannot perform such a robustness check for the remaining 5 crises (which took place in Iceland, India, Indonesia and Japan) as these countries are not recorded in the LIS database which covers OECD countries only.

If we compare our conclusions based on levels of income inequality and those of AM11 based on changes in the levels, there are relevant differences in the classification of countries/crises. For instance, US did not experience a relevant change in income inequality before the 2007 banking crisis (so they fall under the category of "stable" in the AM11 taxonomy), but it is classified as ABOVE according to our criteria. On the other hand, for example, Iceland turns out to be “increasing” in AM11 and BELOW in the classification of our Table 2.

A simple scrutiny of Table 2 suggests at least a couple of remarks. First, there is a sort of "Nordic" exception: all BELOW countries but Germany belong to Northern Europe. Second, and most important, while about two thirds of the banking crises occurred in countries featured by persistently high income inequality, these 8 countries weight much more than two thirds (within the sample) in terms of population, GDP, shares of the international banking sector, and so on. Except for Germany, the most important economies of our (small) sample are ABOVE.

\footnotetext{
${ }^{8}$ Actually, using WIID database instead of the OECD one in computing $G_{i}$ for Germany, this country would cross the threshold and turn out to be ABOVE.

${ }^{9}$ Given the scarcity of LIS data for the relevant period, we use also the value of the Gini coefficient in the year $\mathrm{T}$ of the crisis, whereas in the previous elaboration we considered the period from (T-10) to (T-1). However, for some countries (e.g., Finland), we may be forced to use only one observation. 


\section{Inequality and banking crises: income before-tax and transfers}

We now perform the same exercise through steps (i)-(v) as in Section 3 by looking at incomes before State intervention. Hence, as for step (ii), we concentrate on incomes before-tax and transfers. Data availability allows us to collect statistics on Gini coefficient for the following countries/crises (see Appendix A.1).

\section{[Insert Table 3 here]}

Notice that this larger sample substantially overlaps with the one in Table 1, but now the relative number of banking crises in OECD land shrinks from 11/14 to 8/18 and the new entries are all from South America and Asia.

Similarly to Table 2, next table shows, for each crisis episode, whether the Gini index $G_{i}$ is above or below the OECD average index $G_{O T}$. In this case, we show our conclusions both for the whole sample and for a restricted one which includes only cases for which at least 3 observations were available to compute our average Gini index $G_{i}$. For the former we succeed to collect an average number of 4.5 observations per crisis, while for the latter such number is 7.5.

\section{[Insert Table 4 here]}

Using Gini coefficients for incomes before-tax and transfers, we find that, for the unrestricted sample, banking crises have been preceded by persistently high levels of income inequality in 12 out of 18 cases, whereas in the restricted sample the ratio is 8 out of 9 cases. Again, the relationship between high levels of inequality and the occurrence of banking crises seems to be confirmed. Notice that BELOW countries are either in Northern Europe or in Asia. Moreover, if we go beyond the simple arithmetic, we see that, with the exception of Japan, the largest economies of the sample fall into the ABOVE category (see Figure 2 for the unrestricted sample).

\section{[Insert Figure 2 here]}

The average distance (across crises for countries above the OECD average) from the OECD average is now 0,048 percentage Gini points, with a minimum difference of 0,008 for Italy and a maximum difference of 0,157 for Brazil in 1994. Eliminating these two outliers, the average distance becomes 
0,053. Thus, in general, our conclusions seem again fairly robust to measurement errors and the potential bias induced by outliers.

With respect to the ABOVE/BELOW classifications of Tables 2 and 4, notice that some countries behave differently depending on whether incomes are before- or after-tax and transfers. Germany shows a higher (than OECD average) Gini coefficient before-tax and transfers, but its redistributive policies make its after-tax income inequality falling below the average. Such policies seem comparatively less effective in Indonesia and Japan that stay BELOW in Table 4, but remain ABOVE the OECD average in Table 2.

\section{A further look}

In this section we investigate two issues. The first deals with the pattern of income inequality before and after the banking crises.

We have already seen the levels of Gini coefficients for incomes after tax and transfers - as compared to OECD averages - in the decade preceding a group of banking crises and Table 2 summarizes our conclusions. Now we detect the relative position of each country's income inequality within 5 years (or less, for the 2007-8 crises) after the crisis: more precisely, we compute the average value of Gini coefficient in the period from $(T+1)$ to $(T+6)$. The benchmark is still provided by the OECD average (see Appendix A.2). Table 5 below summarizes the outcome of such test for disposable incomes. We could not replicate the same test for before-tax incomes, due to lack of a sufficient number of observations.

\section{[Insert Table 5 here]}

Only in 11 cases out of 14 we succeed to record the pattern of relative income inequality levels (visà-vis the OECD average) after the crisis. Hence we are left with an even smaller sample; moreover, the number of observations after the 2007/8 banking crises is obviously small too. With these limitations, Table 5 suggests that banking crises do not seem to modify the relative levels of (disposable) income inequality. This finding is consistent with AM11 who, as we noticed in Section 
2, do not discover any typical pattern in income inequality before and after a group of banking crises. $^{10}$

These conclusions contrast with those of Honohan (2005), Bordo and Meissner (2011) as well as with those of Agnello and Sousa (2011). The former concentrates on banking crises in emerging economies in the '90s and find that income inequality generally falls after the episodes. Bordo and Meissner (2011) detect the trend in top income shares in the five years after banking crises occurred between 1880 and 2000 in 16 countries and find that generally financial crises (including banking crises) increase income inequality. Agnello and Sousa (2011) show an inverted V-shape pattern in income inequality before and after banking crises in a large sample of countries in the period 19802006. ${ }^{11}$

Finally, one may wonder whether high inequality (in the sense of ABOVE the average) characterized also countries that did not experience banking crises. Clearly, this would significantly undermine our main conclusions. Thus, the second issue that we tackle in this section deals with the levels of income inequality in countries that did not experience banking crises.

We confine our attention to OECD countries and we distinguish three periods: '80s (1981-1990), '90s (1991-2000) and 2000s (2001-2010). Due to shortage of reliable observations, we limit ourselves to point-wise surveys. Hence, for each country without banking crisis in the relevant decade, we collect the value of Gini coefficient in the year closest to the year in which we record the OECD average (see Appendix A.2); then, we compare the country's Gini value and the OECD average of the same decade. We first consider after-tax incomes (Table 6) and then before-tax incomes (Table 7). For each decade we detect whether a country is above or below the OECD average.

\section{[Insert Table 6 here]}

\section{[Insert Table 7 here]}

\footnotetext{
${ }^{10}$ To be precise, in AM11 after means "in the period from $(E+3)$ to $(E+5)$ if the crisis ends at year $E$ ".

${ }^{11}$ They consider Gini values for a group of 62 countries, identify banking crises through the Reinhart and Rogoff (2009) criteria and estimate a dynamic panel data model on different time horizons. 
Apparently, the lack of banking crises seems uncorrelated with the relative level of disposable income overall inequality. From Table 6 we see that only in the 2000s the number of countries BELOW is greater than the ABOVE one (12 vs. 8), whereas in the ' 80 s (8 vs. 8) and the ' 90 s ( 9 vs. 11) the evidence is even fuzzier than in the last decade. Hence, while Table 2 suggests a nonnegligible association between persistently high levels of income inequality and the occurrence of banking crises, there does not seem to be a significant association between income inequality measures and the lack of banking crises in a fairly large sample of OECD countries.

Similar conclusions hold also for before-tax income inequality, as shown in Table 7. Specifically, the number of countries BELOW vis-à-vis the ABOVE one is 4 vs. 6 in the ' 80 s, 8 vs. 8 in the ' 90 s. In the 2000s, there is a slight majority (12 vs. 7) of countries BELOW the average, as it happened with after-tax incomes collected in Table 6. This last evidence somehow supports our main claim about a positive relationship between income inequality and the occurrence of banking crises.

\section{Concluding remarks}

In this paper we have shown that a large majority of classifiable banking crises in the last thirty years has taken place in countries whose income inequality before the crisis was persistently higher than the OECD relevant average. This conclusion holds true for both incomes after-tax and before-tax and transfers. Moreover, banking crises do not seem to have modified the relative position of income inequality of hosting countries vis-à-vis average OECD levels. Finally, only in the 2000s relatively low income inequality seems associated to the lack of banking crises, whereas in the previous decades we do not detect any clear association.

Developing theoretical arguments that could rationalize these findings goes beyond the scope of our investigation. Different stories might be consistent with the evidence that we have collected. ${ }^{12}$ While we refer to AM11 (p. 43-46) to envisage possible mechanisms through which income inequality can generate a greater risk of crises, we limit ourselves to a few remarks.

First, persistently high levels of (after-tax) income inequality in late '90s and early 2000s may have driven an excess of households borrowing and contributed to undermine banks solidity in a strongly deregulated banking industry. Countries like Spain, UK and USA seem to confirm such mechanism, although we can hardly extend this explanation to other periods/countries.

\footnotetext{
${ }^{12}$ However, with the exception of Kumhof and Ranciere (2010), we are not aware of fairly complete economic models showing a clear relationship between income inequality and financial crises.
} 
Second, persistently high levels of (before-tax) income inequality may have induced policy makers to increase redistribution through large public expenditure and taxation along mechanisms like those pioneered by Meltzer and Richard (1981) and later extended to growth by Alesina and Rodrik (1994) and Persson and Tabellini (1994). Worsening public deficits and debts (and rising interest rates), such policies may have depressed growth and ultimately deteriorated banks stability.

Third, one may notice that some countries seem characterized by structurally high or structurally levels of income inequality. Among the former, we may mention Argentina and Brazil, whereas Nordic countries seem to belong the latter group. For all these countries, the association between levels of income inequality and banking crises (or the lack of them) could be interpreted as a coincidence.

It is well known that there is a serious data challenge in exploring income distribution, especially as far as cross-countries analyses of income inequality are concerned. Optimizing the quality of data (in terms of time consistency and international comparability) unavoidably shrinks the size of samples. However, we have successfully used LIS data to check the robustness of our conclusions regarding after-tax incomes. Moreover, the average distances of countries Gini coefficients from the thresholds seem large enough to protect our findings from measurement errors.

Finally, we have remarked that the analysis should go beyond the simple arithmetic of counting crises/countries. Almost all biggest economies of our samples (listed in Tables 1 and 3) fit our main conclusion about a positive association between persistently high levels of income inequality and the occurrence of banking crises. So, as long as high income inequality is associated to banking crises in "big" countries, then such inequality should be of some concern for the whole system, given the interdependency of financial markets and the resulting contagion outside national boundaries. 


\section{References}

Agnello, L., Sousa R. M., 2011, “How do banking crises impact on income inequality?”, NIPE Working Paper 30/2011.

Alesina A., Rodrik D., 1994, “Distributive Politics and Economic Growth”, Quarterly Journal of Economics, 109, 465-89.

Atkinson A., Morelli S., 2011, “Economic Crises and Inequality”, UNDP, Research Paper 2011/6.

Atkinson A., Morelli S., 2012, “Chartbook of Economic Inequality: 25 Countries 1911-2010”, Inet Research Note 015.

Atkinson A., Piketty T., Saez E., 2011, “Top incomes in the long run of history”, Journal of Economic Literature, 49, 3-71.

Bordo M., Eichengreen B., Klingebiel D., Martina-Peria, M.. 2001, "Is the crisis problem growing more severe?”, Economic Policy, 32, 51-82.

Bordo M., Meissner C., 2011, "Do financial crises always raise inequality? Some evidence from history”, mimeo.

Bordo M., Meissner C., 2012, “Does inequality lead to a financial crisis?”, Journal of International Money and Finance, 31, 2147-61.

Fitoussi J.-P., Saraceno F., 2009, "How deep is a crisis? Policy responses and structural factors behind diverging performances”, OFCE/POLHIA 2009-31.

Glaiser E., 2010, http://Economix.blogs,nytimes.com/2010/12/14/does-economic-inequality-causecrises/

Honohan, P., 2005, “Banking Sector Crises and Inequality”, World Bank Policy Research Working Paper 3659.

Kumhof M., Ranciere R., 2010, “Inequality, Leverage and Crises”, IMF, Working Paper 10/268.

Krugman P., 2012, End This Depression Now!, Melrose Road Partners, New York.

Laeven L., Valencia F., 2008, “Systemic Banking Crises: A New Database”, IMF, Working Paper $08 / 224$.

Laeven L., Valencia F., 2010, “Resolution of Banking Crises: The Good, the Bad, and the Ugly”, IMF, Working Paper 10/146.

Luxembourg Income Studies (LIS), “Key Inequality Worldbook”, 13/2/2013.

Meltzer A.H., Richard S.F., 1981, “A Rational Theory of the Size of the Government”, Journal of Political Economy, 89, 914-927. 
Milanovic B., 2012, The Haves and Have-Nots. A Brief Hidiosyncratic History of Global Inequality, Basic Books, New York.

OECD, 2011, “Divided We Stand: Why Inequality Keeps Rising”, Paris.

Persson T., Tabellini G., 1994, "Is Inequality Harmful to Growth? Theory and Evidence”, American Economic Review, 84, 600-21.

Rajan R., 2010, Fault Lines, Princeton University Press, Princeton.

Reinhart C., Rogoff K., 2009, This Time is Different, Princeton University Press, Princeton.

Stiglitz J., 2012, The Price of Inequality, Norton, New York.

Stockhammer E., 2012, "Rising Inequality as a Root Cause of the Present Crisis” PERI Working Paper 282.

Story, L., 2010, “Income Inequality and Financial Crises”, New York Times, August 21.

UNU-WIDER (2008), “World Income Inequality Database (WIID)”, Version 2.0.c, May.

Van Treeck T., Sturn S., 2012, "Income inequality as a cause of the great recession? A survey of current debates”, ILO Series No. 39, Geneva. 


\section{Appendix}

\section{A.1 The dataset ${ }^{13}$}

In selecting data sources on Gini coefficient for countries of our sample of Table 2, we use the following lexicographic criterion: (1) at least three years in the relevant period [T-10, T-1]; (2) the dataset by Atkinson and Morelli (2012) - AM12 henceforth ${ }^{14}$ - or the longest time series between OECD (2011, Overview, Fig. 2) and WIID (UNU-WIDER, 2008).

As for data in Table 4, for the restricted sample we use at least three observations from OECD (2011, Dataset: Income Distribution) or WIID. For the unrestricted sample, we use at least two observations available from either source.

For each country/crisis, we now specify the statistical source and the years of available data. We begin from countries/crises listed in Table 2.

FINLAND (1991): AM12; 1987-1990.

GERMANY (2007): AM12; 1997-2006.

ICELAND (2007): AM12; 2003-6.

INDIA (1993): AM12; 1983-1992.

INDONESIA (1992): AM12; 1984, 1987, 1990.

INDONESIA (1997): AM12; 1990, 1993, 1996.

ITALY (1990): AM12; 1981-84, 1986, 1987, 1989.

JAPAN (1992): WIID; 1986, 1989, 1992; Notice that only in this case, for this sample, we use the year of the crisis to reach the minimum number of three observations.

NETHERLANDS (2008); AM12, 1998-2007.

SPAIN (2008): WIID; 1999-2002, 2004-2006.

SWEDEN (1991): AM12; 1981-90.

UNITED KINGDOM (2007): AM12; 1997-2006.

UNITED STATES (1984): OECD; 1979-1983.

UNITED STATES (2007): OECD; 1997-2006.

We now report the same type of information for countries/crises listed in Table 4. Notice that there are some overlaps of observations among crises: 2 between Argentina 1989 and 1995; 4 between Argentina 1995 and 2001; 6 between Brazil 1990 and 1994.

ARGENTINA (1989): WIID; 1983, 1985, 1987, 1988.

\footnotetext{
${ }^{13}$ All data used to create Tables 2, 4, 5, 6 and 7 are recorded in Excel sheets available upon request.

${ }^{14}$ AM12 have done an excellent work in selecting data from different datasets to ease consistency over time. 
ARGENTINA (1995): WIID; 1987- 1989, 1991-94.

ARGENTINA (2001): WIID; 1991-2000.

BRAZIL (1990): WIID; 1980, 1981, 1983-89.

BRAZIL (1994): WIID; 1984-90, 1992, 1993.

GERMANY (2007): OECD; 2000, 2005.

INDONESIA (1992): WIID; 1984, 1990.

INDONESIA (1997): WIID; 1990, 1993.

ITALY (1990): OECD; 1985, 1990. Notice that we use the year of the crisis to reach the number of two observations.

JAPAN (1992): WIID; 1982-1986.

MALAYSIA (1985): WIID; 1976, 1979, 1984.

MALAYSIA (1997): WIID; 1990, 1997. Notice that we use the year of the crisis to reach the number of two observations.

NETHERLANDS (2008): OECD; 2000, 2005.

SINGAPORE (1982): WIID; 1972-1981.

SWEDEN (1991): OECD; 1985, 1990.

UNITED KINGDOM (2007): OECD; 2000, 2005.

UNITED STATES (1984): WIID; 1974-1983.

UNITED STATES (2007): OECD; 2000, 2005.

\section{A.2 The benchmarks}

As for the computation of the benchmarks behind columns 3 and 4 of Table 2, we proceed as follows. In the ten years before the crisis we record the average value of Gini coefficients for OECD countries using two different sources: OECD for column 3 and LIS for column 4 . When the source is OECD, notice that Gini values are provided "around" every 5 years (OECD 2011, p. 25): mid80s, around 1990, and so on. In correspondence of these "focal" years, we calculate the OECD average. Hence, in the relevant decade before the crisis (with a couple of exceptions, see footnotes 17 and 18), we have two averages and in such a case we average them. Table A.1 collects such benchmarks for each country/crisis. The second column reports the focal years in which OECD provides data that we average and show in column 3 (in brackets is the number of countries concurring to the average). Remember that the number of OECD members has been growing over time. As for the benchmark built on LIS database - as LIS does not provide averages for the OECD group - we use the values of Gini coefficient available for OECD countries: for each country we select the closest year before the corresponding focal year(s) of column 2 and then we average across countries. The outcome, for each country/crisis, is reported in column 4 of Table A.1: again, in brackets is the number of countries contributing to the average. ${ }^{15}$

\footnotetext{
${ }^{15}$ For instance, 0.294 is the relevant value of the OECD benchmark for Finland when using OECD data; such number is obtained by averaging the "mid-80s" OECD average (calculated as average of 22 OECD 17
} 
Table A.1. The benchmarks of Table 2

\begin{tabular}{|llll|}
\hline Country (year of the crisis) & $\begin{array}{l}\text { Focal OECD years } \\
\text { (around) }\end{array}$ & $\begin{array}{l}\text { OECD average } \\
\text { (source: OECD) }\end{array}$ & $\begin{array}{l}\text { OECD average } \\
\text { (source: LIS) }\end{array}$ \\
\hline Finland (1991) & 1985,1990 & $0,294(22,15)$ & $0,271(18,18)$ \\
\hline Germany (2007) & 2000,2000 & $0,313(27,34)$ & $0,295(24,24)$ \\
\hline Iceland (2007) & 2000,2005 & $0,313(27,34)$ & $0,295(24,24)$ \\
\hline India (1993) & 1985,1990 & $0,294(22,15)$ & $0,271(18,18)$ \\
\hline Indonesia (1992) & 1985,1990 & $0,294(22,15)$ & $0,271(18,18)$ \\
\hline Indonesia (1997) & 1990,1995 & $0,300(15,27)$ & $0,281(18,21)$ \\
\hline Italy (1990) & $1985,1990^{17}$ & $0,294(22,15)$ & $0,271(18)$ \\
\hline Japan (1992) & 1985,1990 & $0,294(22,15)$ & $0,271(18,18)$ \\
\hline Netherlands (2007) & 2000,2005 & $0,313(27,34)$ & $0,295(24,24)$ \\
\hline Spain (2008) & 2000,2005 & $0,313(27,34)$ & $0,295(24,24)$ \\
\hline Sweden (1991) & 1985,1990 & $0,294(22,15)$ & $0,271(18,18)$ \\
\hline United Kingdom (2007) & 2000,2005 & $0,313(27,34)$ & $0,295(24,24)$ \\
\hline United States (1984) & $1975,1985^{18}$ & $0,291(8,22)$ & $0,271(18)$ \\
\hline United States (2007) & 2000,2005 & $0,313(27,34)$ & $0,295(24,24)$ \\
\hline
\end{tabular}

The same procedure undertaken to build the benchmarks of Table 2 (incomes after-tax and transfers) is now used to build the benchmarks of Table 4 (incomes before-tax and transfers).

members) and the "around 1990" OECD average (calculated as average of 15 OECD members). The same procedure has been used to build column 4 with LIS data.

${ }^{16}$ We label 1975, 1985, 1995 and 2005 the years that OECD labels “mid-70s”, “mid-80s”, "mid-90s” and “mid-2000s”, respectively.

${ }^{17}$ OECD does not provide Gini values "around 1980". This is why we take 1990 as additional focal year, although it is the year of the Italian banking crisis.

${ }^{18}$ See footnote 17 . This is why we take 1985 as additional focal year, although it is (immediately) after the 1984 American banking crisis. 
Table A.2. The benchmarks of Table 4

\begin{tabular}{|lll|}
\hline Country (year of the crisis) & $\begin{array}{l}\text { Focal OECD } \\
\text { years (around) }\end{array}$ & $\begin{array}{l}\text { OECD average } \\
\text { (source: OECD) }\end{array}$ \\
\hline Argentina (1989) & 1985 & $0,412(17)$ \\
\hline Argentina (1995) & 1985,1990 & $0,424(17,12)$ \\
\hline Argentina (2001) & 1995,2000 & $0,466(23,22)$ \\
\hline Brazil (1990) & 1985,1990 & $0,424(17,12)$ \\
\hline Brazil (1994) & 1985,1990 & $0,424(17,12)$ \\
\hline Germany (2007) & 2000,2005 & $0,462(22,33)$ \\
\hline Indonesia (1992) & 1985,1990 & $0,424(17,12)$ \\
\hline Indonesia (1997) & 1990,1995 & $0,451(12,23)$ \\
\hline Italy (1990) & 1985,1990 & $0,424(17,12)$ \\
\hline Japan (1992) & 1985,1990 & $0,424(17,12)$ \\
\hline Malaysia (1985) & 1975,1985 & $0,405(8,17)$ \\
\hline Malaysia (1997) & 1990,1995 & $0,451(12,23)$ \\
\hline Netherlands (2008) & 2000,2005 & $0,462(22,33)$ \\
\hline Singapore (1982) & 1975 & $0,399(8)$ \\
\hline Sweden (1991) & 1985,1990 & $0,424(17,12)$ \\
\hline United Kingdom (2007) & 2000,2005 & $0,462(22,33)$ \\
\hline United States (1984) & 1975 & $0,399(8)$ \\
\hline United States (2007) & 2000,2005 & $0,462(22,33)$ \\
\hline
\end{tabular}

Finally, we collect the benchmarks of Table 5 which takes into account also post-crises periods. The number of countries entering the OECD averages are already listed in Table A.1 above; in the "late 2000s” such number is 34 .

\footnotetext{
${ }^{19}$ Notice that for Argentina 1989, Singapore 1982 and United States 1984, a focal OECD year would be "around 1980", but Gini coefficient for such year is not provided by OECD and we are left with one focal year only. For the same reason, in the benchmark for Brazil 1990 and Italy we take 1985 and 1990, whereas for Malaysia 1985 we take 1975 and 1985. 
Table A.3. The benchmarks of Table 5

\begin{tabular}{|c|c|c|c|c|}
\hline $\begin{array}{l}\text { Country (year of the } \\
\text { crisis) }\end{array}$ & $\begin{array}{l}\text { Focal OECD } \\
\text { years (around) } \\
\text { before crisis }\end{array}$ & $\begin{array}{l}\text { OECD average } \\
\text { (source: OECD) } \\
\text { before crisis }\end{array}$ & $\begin{array}{l}\text { Focal OECD } \\
\text { years (around) } \\
\text { after crisis }\end{array}$ & $\begin{array}{l}\text { OECD average (source: } \\
\text { OECD) after crisis }\end{array}$ \\
\hline Finland (1991) & 1985,1990 & 0,294 & 1995 & 0,304 \\
\hline Germany (2007) & 2000,2005 & 0,313 & Late 2000s & 0,314 \\
\hline Iceland (2007) & 2000,2005 & 0,313 & Late 2000s & 0,314 \\
\hline India (1993) & 1985,1990 & 0,294 & 1995 & 0,304 \\
\hline Indonesia (1992) & 1985,1990 & 0,294 & 1995 & 0,304 \\
\hline Indonesia (1997) & 1990,1995 & 0,300 & 2000 & 0,310 \\
\hline Italy (1990) & 1985,1990 & 0,294 & 1990,1995 & 0,300 \\
\hline Japan (1992) & 1985,1990 & 0,294 & 1995 & 0,304 \\
\hline Netherlands (2007) & 2000,2005 & 0,313 & Late 2000s & 0,314 \\
\hline Spain (2008) & 2000,2005 & 0,313 & Late 2000s & 0,314 \\
\hline Sweden (1991) & 1985,1990 & 0,294 & 1995 & 0,304 \\
\hline $\begin{array}{ll}\text { United } & \text { Kingdom } \\
(2007) & \end{array}$ & 2000,2005 & 0,313 & Late 2000s & 0,314 \\
\hline United States (1984) & 1975,1985 & 0,291 & 1985,1990 & 0,294 \\
\hline United States (2007) & 2000,2005 & 0,313 & Late 2000s & 0,314 \\
\hline
\end{tabular}


Tables and Figures

Table 1 . The first sample of 14 banking crises: 1984-2008

\begin{tabular}{|cc|}
\hline Country & Year \\
\hline Finland & 1991 \\
\hline Germany & 2007 \\
\hline Iceland & 2007 \\
\hline India & 1993 \\
\hline Indonesia & 1992,1997 \\
\hline Italy & 1990 \\
\hline Japan & 1992 \\
\hline Netherlands & 2008 \\
\hline Spain & 2008 \\
\hline Sweden & 1991 \\
\hline United Kingdom & 2007 \\
\hline United States & 1984,2007 \\
\hline
\end{tabular}

Table 2. After-tax income inequality and banking crises

\begin{tabular}{|llll|} 
Country & Year & $\begin{array}{l}\text { Relative to } \\
\text { OECD } \\
\text { average } \\
\text { (source: } \\
\text { OECD) }\end{array}$ & $\begin{array}{l}\text { Relative to } \\
\text { OECD } \\
\text { average } \\
\text { (source: } \\
\text { LIS) }\end{array}$ \\
\hline Finland & 1991 & BELOW & BELOW \\
\hline Germany & 2007 & BELOW & BELOW \\
\hline Iceland & 2007 & BELOW & BELOW \\
\hline India & 1993 & ABOVE & ABOVE \\
\hline Indonesia & 1992 & ABOVE & ABOVE \\
\hline Indonesia & 1997 & ABOVE & ABOVE \\
\hline Italy & 1990 & ABOVE & ABOVE \\
\hline Japan & 1992 & ABOVE & ABOVE \\
\hline Netherlands & 2008 & BELOW & BELOW \\
\hline Spain & 2008 & ABOVE & ABOVE \\
\hline Sweden & 1991 & BELOW & BELOW \\
\hline United Kingdom & 2007 & ABOVE & ABOVE \\
\hline United States & 1984 & ABOVE & ABOVE \\
\hline United States & 2007 & ABOVE & ABOVE \\
\hline
\end{tabular}


Table 3. The second sample of 18 banking crises: 1982-2008

\begin{tabular}{|ll|}
\hline Country & Year \\
\hline Argentina & $1989,1995,2001$ \\
\hline Brazil & 1990,1994 \\
\hline Germany & 2007 \\
\hline Indonesia & 1992,1997 \\
\hline Italy & 1990 \\
\hline Japan & 1992 \\
\hline Malaysia & 1985,1997 \\
\hline Netherlands & 2008 \\
\hline Singapore & 1982 \\
\hline Sweden & 1991 \\
\hline United Kingdom & 2007 \\
\hline United States & 1984,2007 \\
\hline
\end{tabular}

Table 4. Before-tax income inequality and banking crises

\begin{tabular}{|llll|}
\hline Country & Year & $\begin{array}{l}\text { Whole } \\
\text { sample }\end{array}$ & $\begin{array}{l}\text { Restricted } \\
\text { sample }\end{array}$ \\
\hline Argentina & 1989 & ABOVE & ABOVE \\
\hline Argentina & 1995 & ABOVE & ABOVE \\
\hline Argentina & 2001 & ABOVE & ABOVE \\
\hline Brazil & 1990 & ABOVE & ABOVE \\
\hline Brazil & 1994 & ABOVE & ABOVE \\
\hline Germany & 2007 & ABOVE & \\
\hline Indonesia & 1992 & BELOW & \\
\hline Indonesia & 1997 & BELOW & \\
\hline Italy & 1990 & ABOVE & \\
\hline Japan & 1992 & BELOW & BELOW \\
\hline Malaysia & 1985 & ABOVE & ABOVE \\
\hline Malaysia & 1997 & BELOW & \\
\hline Netherlands & 2008 & BELOW & \\
\hline Singapore & 1982 & ABOVE & ABOVE \\
\hline Sweden & 1991 & BELOW & \\
\hline United Kingdom & 2007 & ABOVE & \\
\hline United States & 1984 & ABOVE & ABOVE \\
\hline United States & 2007 & ABOVE & \\
\hline
\end{tabular}


Table 5. Inequality Above or Below the OECD average before and after 14 banking crises (incomes after-tax and transfers)

\begin{tabular}{|ll|}
$\begin{array}{l}\text { Country (year of the } \\
\text { crisis) }\end{array}$ & $\begin{array}{l}\text { Pattern before and after } \\
\text { the crisis }\end{array}$ \\
\hline Finland (1991) & Below/Below \\
\hline Germany (2007) & Below/Below \\
\hline Iceland (2007) & Below/Below \\
\hline India (1993) & Above/n. a. \\
\hline Indonesia (1992) & Above/Above \\
\hline Indonesia (1997) & Above/n. a. \\
\hline Italy (1990) & Above/Above \\
\hline Japan (1992) & Above/Above \\
\hline Netherlands (2007) & Below/Below \\
\hline Spain (2008) & Above/ n. a. \\
\hline Sweden (1991) & Below/Below \\
\hline $\begin{array}{l}\text { United Kingdom } \\
\text { (2007) }\end{array}$ & Above/Above \\
\hline United States (1984) & Above/Above \\
\hline United States (2007) & Above/Above \\
\hline
\end{tabular}

\footnotetext{
${ }^{20}$ Notice that only for Indonesia, in Table 5, we allow for an overlap of reference periods between different crises: observations for 1993 and 1996 belong indeed to the pre-1997 crisis as well as to the post-1992 crisis. 
Table 6. Inequality Above or Below the OECD average (incomes after-tax and transfers) in 25 OECD countries: $b$. $c$. means banking crisis in the decade; $n \mathrm{~m}$. means that the country was not member of OECD in the decade; $n$. $a$. means that the data for the country is not available in the period. (Source: LIS)

\begin{tabular}{|llll|}
\hline Countries & '80s & 90s & 2000s \\
\hline Australia & Above & Above & Above \\
\hline Austria & Below & Below & Below \\
\hline Belgium & Below & Below & Below \\
\hline Canada & Above & Above & Above \\
\hline Czech Republic & n. m. & Below & Below \\
\hline Denmark & Below & Below & Below \\
\hline Finland & Below & b. c. & Below \\
\hline France & Above & Above & Below \\
\hline Germany & Below & Below & b. c. \\
\hline Greece & n. a. & Above & Above \\
\hline Hungary & n. m. & Above & Above \\
\hline Ireland & Above & Above & Above \\
\hline Italy & b. c. & Above & Above \\
\hline Luxembourg & Below & Below & Below \\
\hline Mexico & n. m. & Above & Above \\
\hline Netherlands & Below & Below & b. c. \\
\hline Norway & b. c. & Below & Below \\
\hline Poland & n. m. & Above & Above \\
\hline Slovak Republic & n. m. & Below & Below \\
\hline Slovenia & n. m. & n. m. & Below \\
\hline Spain & Above & n. a. & b. c. \\
\hline Sweden & Below & b. c. & Below \\
\hline Switzerland & Above & Above & Below \\
\hline United Kingdom & Above & Above & b. c. \\
\hline United States & b. c. & Above & b. c. \\
\hline
\end{tabular}


Table 7. Inequality Above or Below the OECD average (incomes before-tax and transfers) in 16 OECD countries: $b$. $c$. means banking crisis in the decade; $n \mathrm{~m}$. means that the country was not member of OECD in the decade; $n$. $a$. means that the data for the country is not available in the period. (Source: OECD)

\begin{tabular}{|llll|}
\hline Countries & '80s & '90s & 2000s \\
\hline Australia & n. a. & Above & Below \\
\hline Austria & n. a. & n. a. & Below \\
\hline Belgium & Above & Above & Above \\
\hline Canada & Below & Below & Below \\
\hline Czech Republic & n. m. & Below & Above \\
\hline Denmark & Below & Below & Below \\
\hline Finland & Above & b. c. & Below \\
\hline France & n. a. & Above & Above \\
\hline Germany & Above & Below & b. c. \\
\hline Greece & Above & Below & Below \\
\hline Hungary & n. m. & Above & Above \\
\hline Italy & b. c. & Above & Above \\
\hline Luxembourg & Below & Below & Below \\
\hline Mexico & n. m. & Above & Above \\
\hline Netherlands & Above & Above & b. c. \\
\hline Norway & b. c. & Below & Below \\
\hline
\end{tabular}




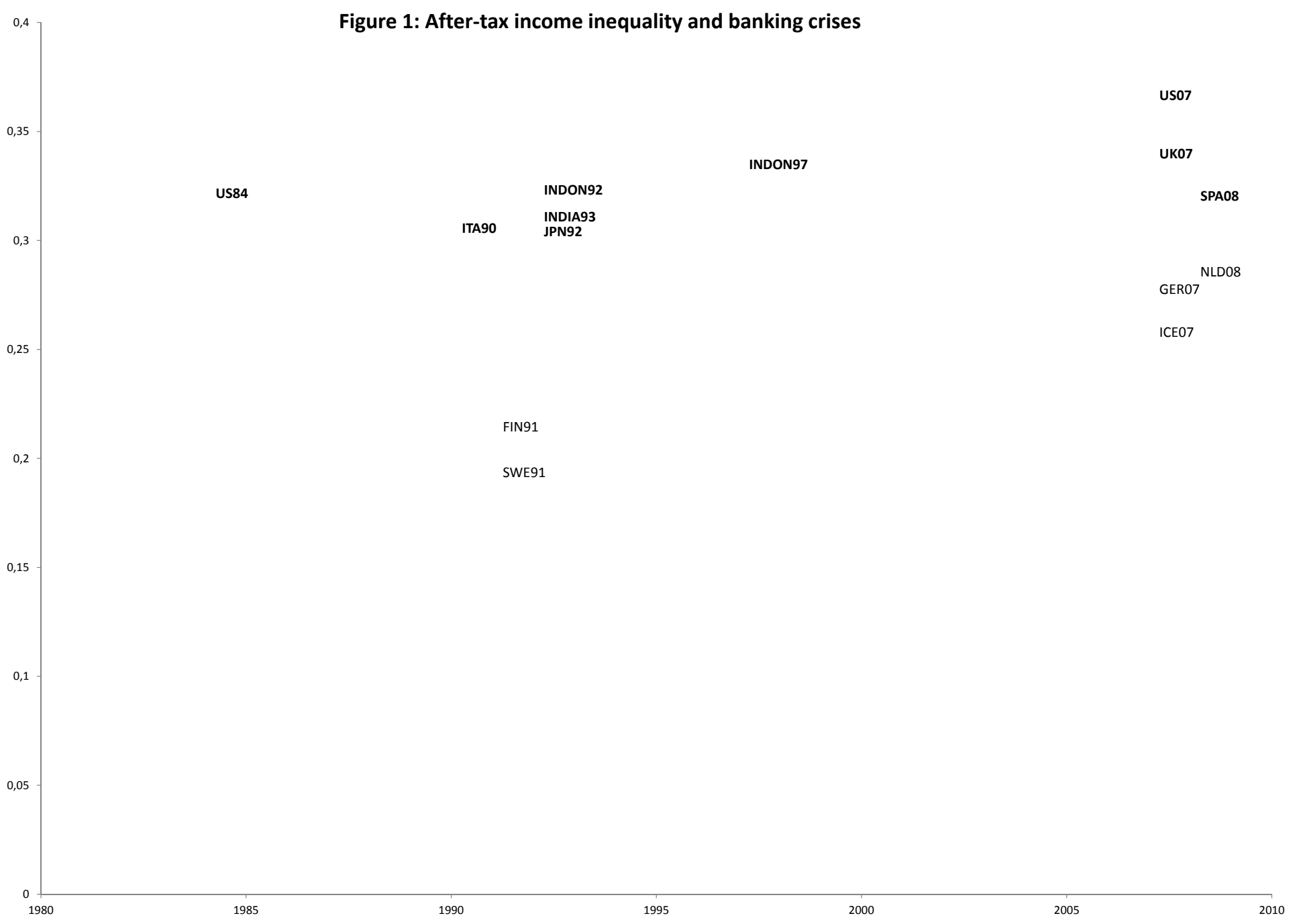

Countries in bold are ABOVE the timely OECD average. 


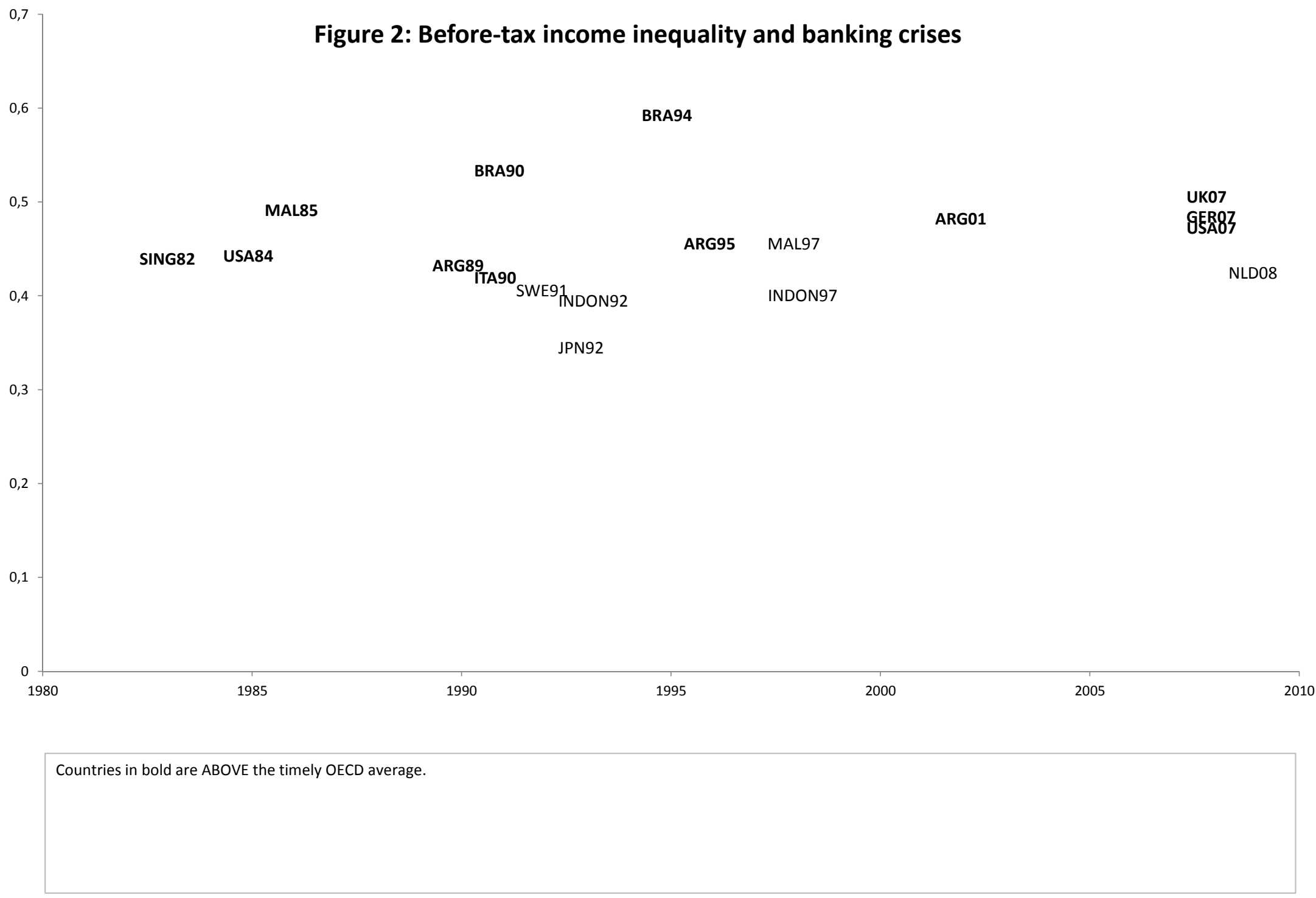




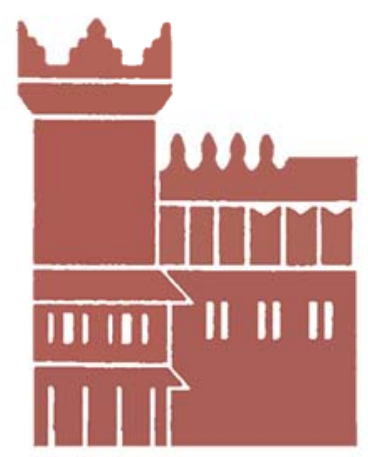

Alma Mater Studiorum - Università di Bologna DEPARTMENT OF ECONOMICS

Strada Maggiore 45

40125 Bologna - Italy

Tel. +39051 2092604

Fax +390512092664

http://www.dse.unibo.it 